\title{
PENGARUH PENDAPATAN ASLI DAERAH, DANA ALOKASI UMUM DAN DANA ALOKASI KHUSUS TERHADAP INDEKS PEMBANGUNAN MANUSIA DENGAN BELANJA MODAL SEBAGAI VARIABEL INTERVENING
}

(Studi Empiris pada Kabupaten dan Kota di Sumatera Barat Tahun 2015-2017)

\author{
Adel Riviando ${ }^{1}$, Henri Agustin ${ }^{2}$, Halmawati ${ }^{3}$ \\ 1) Alumni Jurusan AkuntansiFakultas Ekonomi, Universitas Negeri Padang \\ 2,3) Jurusan Akuntansi Fakultas Ekonomi, Universitas Negeri Padang \\ *Korespondensi: adelriviando09@gmail.com
}

\begin{abstract}
This research aims to prove empirically the influence of PAD, DAU and DAK on the HDI with Capital Expenditure as an Intervening variable. This is quantitative descriptive research. The population in this research were 19 districts and cities in the Province of West Sumatra in 2015-2017. The PAD variable is measured by the PAD formula $=\%$ allocation forming the HDI $\times$ total PAD, the DAU variable measured by the DAU formula $=\%$ allocation forming the HDI $\times$ the total DAU, the DAK variable measured DAK formula $=\%$ allocation of HDI maker $\times$ total DAK, variable Capital Expenditures measured by Capital Expenditure $=\%$ allocation of HDI formers $\times$ total Capital Expenditures and HDI measured through the average of 3 components forming the HDI. Samples in this study were determined by the total sampling method. The type of data used is secondary data obtained from www.bps.go.id and www.djpk.depkeu.go.id. The analytical method used is Partial Least Square. The results of this study shows that PAD, DAU and DAK have a significant positive effect on the HDI, Capital Expenditures are not able to mediate the influence of PAD, DAU and DAK on the HDI.
\end{abstract}

Keywords: Regional Original Income (PAD), General Allocation Fund (DAU), Special Allocation Fund (DAK), Capital Expenditures, Human Development Index (HDI)

\section{How to cite (APA $6^{\text {th }}$ style)}

Riviando, Adel, Agustin, Henri, Halmawati. (2019). Pengaruh Pendapatan Asli Daerah, Dana Alokasi Umum, Dana Alokasi Khusus Terhadap Indeks Pembangunan Manusia dengan Belanja Modal Sebagai Variabel Intervening (Studi Empiris pada Kabupaten dan Kota di Sumatera Barat Tahun 2015-2017. Jurnal Eksplorasi Akuntansi, 1(1) Seri A, 1-17.

\section{PENDAHULUAN}

Manusia merupakan salah satu dari modal penting dalam menuju pembangunan ekonomi yang lebih baik kedepannya. Manusia sebagai salah satu dari objek pembangunan ekonomi, manusia juga merupakan salah satu subjek penting dalam tujuan pembangunan ini. Dalam amanat 
pembukaan Undang-Undang Dasar Negara Republik Indonesia tahun 1945 disana tercantum tujuan bernegara yaitunya "memajukan kesejahteraan umum dan mencerdaskan kehidupan bangsa".

Peningkatan SDM mempunyai makna peningkatan kapasitas dasar penduduk, sehingga dapat memperbesar kesempatan untuk dapat berpartisipasi dalam proses pembangunan. SDM yang berkualitas tinggi merupakan modal yang paling penting dalam pembangunan yang akan berperan aktif dalam proses pembangunan itu sendiri. Salah satu upaya yang harus dilakukan oleh pemerintah untuk mewujudkan suatu pembangunan nasional adalah meningkatkan kualitas pembangunan manusia.

IPM bertujuan mengukur seberapa besar pencapaian pembangunan manusia yang berbasis dari sejumlah komponen-komponen dasar dari kulitas hidup manusia. Sebagai ukuran dari kualitas hidup, Indeks Pembangunan Manusia dibangun melalui tiga dimensi pendekatan dasar yaitu: kehidupan yang layak, pengetahuan dan umur panjang dan sehat (www.bps.go.id). Ketiga unsur tersebut tidak bisa berdiri sendiri, melainkan saling mempengaruhi satu dengan yang lainnya.

Sumber dari penerimaan daerah dalam pelaksanaan desentralisasi yang pertama adalah PAD. PAD merupakan pendapatan asli daerah yang diperoleh sesuai dengan Peraturan Daerah dan peraturan perundang-undangan. Sumber penerimaan daerah yang kedua adalah DAU. DAU adalah dana yang bersumber dari APBN dengan tujuan pemerataan kemampuan keuangan antar daerah untuk mendanai kebutuhan daerah dalam rangka pelaksanaan desentralisasi Sumber dana daerah selanjutnya yaitu DAK. Alokasi DAK mempertimbangkan ketersediaan dana dalam APBN, sehingga besaran DAK tidak pasti setiap tahunnya. Tujuan penggunaan DAK dapat diarahkan pada upaya untuk meningkatkan IPM yang merupakan salah satu isu nasional yang harus dituntaskan.

Perbedaan dari hasil penelitian sebelumnya maka mendorong peneliti untuk melakukan penelitian ulang mengenai pengaruh PAD, DAU dan DAK terhadap IPM dengan Belanja Modal sebagai varibel intervening. Upaya perbaikan penelitian ini juga dilakukan dengan memperbaharui tempat penelitian dan model penelitian yang berbeda dengan penelitian sebelumnya, yaitu dengan melakukan penelitian di wilayah pemerintahan kabupaten dan kota di Provinsi Sumatera Barat dan dengan melakukan penelitian pengaruh langsung dan tidak langsung variabel PAD terhadap IPM melalui Belanja Modal sebagai pemediasi. Adanya ketidakkonsistenan hasil penelitian terdahulu mengenai pengaruh DAU terhadap IPM melalui Belanja Modal. Unit analisis dari penelitian ini adalah Provinsi Sumatera Barat. Provinsi Sumatera Barat dipilih karena menurut data dari republika.co.id menunjukan bahwasanya angka IPM untuk Provinsi Sumatera Barat menunjukan peningkatan setiap tahunnya dan bahkan IPM dari Provinsi Sumatera Barat ditahun 2017 melebihi angka IPM rata-rata nasional.

Tujuan penelitian ini adalah untuk memberikan bukti empiris dan melengkapi literatur mengenai pengaruh Pendapatan Asli Daerah, Dana Alokasi Umum, Dana Alokasi Khusus dan Belanja Modal terhadapa IPM serta Memberikan sumbangan pemikiran bagi Lembaga-lembaga terkait dalam bagaimana menentukan kebijakannya yang berkaitan dengan IPM.

\section{REVIU LITERATUR DAN HIPOTESIS \\ Teori Keagenan (Agency Theory)}

Keterkaitan teori keagenan dalam penelitian ini dapat dilihat melalui hubungan antara pemerintah pusat dan pemerintah daerah dalam distribusi dana perimbangan serta hubungan antara 
masyarakat yang diproksi oleh DPRD sebagai prinsipal dan pemerintah daerah sebagai agen. Pemerintah pusat mendelegasikan wewenangnya kepada pemerintah daerah dalam mengelola rumah tangga mereka sendiri. Oleh karena itu, konsekuensi dari pendelegasian wewenang, pemerintah pusat telah menyalurkan dana perimbangan, yang tujuannya adalah guna membantu pemerintah daerah dalam mendanai kebutuhan tata kelola sehari-hari dan dalam menyediakan layanan publik yang lebih baik kepada masyarakat. Selain itu, teori agensi juga tersirat dalam hubungan antara pemerintah daerah dan masyarakat. Masyarakat sebagai prinsipal menyediakan sumber daya bagi daerah dengan pembayaran pajak daerah, retribusi daerah dan lain-lain ntuk meningkatkan pendapatan daerah itu sendiri.

\section{Pendapatan Asli Daerah}

Menurut UU Nomor 33 Tahun 2004, PAD merupakan suatu penerimaan yang diperoleh daerah dari berbagai sumber yang ada di daerah tersebut dan dipungut berdasarkan peraturan daerah sesuai dengan peraturan perundang-undangan yang berlaku. PAD merupakan pendapatan yang penting untuk pembiayaan daerah, karenanya kemampuan dalam melaksanakan ekonomi dapat diukur berdasarkan besarnya kontribusi yang diberikan oleh PAD terhadap APBD, semakin besar kontribusi PAD terhadap APBD berarti semakin kecil ketergantungan pemerintah daerah terhadap bantuan dari pemerintah pusat. Dalam UU Nomor 33 Tahun 2004 Pasal 6, sumbersumber PAD terdiri dari: (1) pajak daerah, (2) retribusi daerah, (3) hasil pengelolaan kekayaan daerah yang dipisahkan dan (4) lain-lain PAD yang sah.

\section{Dana Perimbangan}

Peraturan Pemerintah Nomor 55 tahun 2005 mengenai Dana Perimbangan, dana perimbangan ialah dana yang bersumber dari pendapatan APBN yang dialokasikan kepada daerah untuk mendanai kebutuhan daerah dalam rangka pelaksanaan desentralisasi. Untuk menjalankan urusan pemerintahan, daerah harus memiliki sumber keuangan supaya mampu memberikan pelayanan dan kesejahteraan kepada masyarakat. pengalokasian sumber keuangan kepada pemerintah daerah harus setara dengan beban atau urusan pemerintahan yang telah diserahkan kepada pemerintah daerah. Keseimbangan tersebut menjadi jaminan terselenggaranya urusan pemerintahan yang di selenggarakan oleh pemerintah daerah. Dana perimbangan ini dibagi menjadi:

\section{Dana Alokasi Umum}

DAU adalah salah satu dari Dana Perimbangan yang memperoleh alokasi anggaran transfer dari Pemerintah Pusat. Pada dasarnya transfer ini dikelompokan menjadi dua kategori, yaitu: (1) transfer tanpa syarat (unconditional grants, general purpose rant, block grant), (2) transfer dengan syarat (conditional grant, categorical grant, specific purpose grant). Sesuai dengan Undangundang Nomor 33 Tahun 2004 DAU berpengaruh dalam pemerataan horizontal (horizontal equalization), yaitu dengan menutup celah fiskal (fiscal gap) antara potensi ekonomi dan kebutuhan fiskal yang dimiliki oleh daerah. DAU sering disebut bantuan tak bersyarat (unconditional grants) karna DAU merupakan jenis transfer antartingkat pemerintah yang tidak terikat dari program pengeluaran tertentu. 


\section{Dana Alokasi Khusus}

DAK adalah dana yang bersumber dari APBN, kemudian dialokasikan kepada daerah untuk membiayai kebutuhan khusus yang merupakan urusan daerah dan sesuai dengan prioritas nasional dengan memperhatikan ketersediaan dana dalam APBN. Sesuai dengan Undang-undang Nomor 23 Tahun 2014. Dalam pasal 40 UU No. 33 tahun 2004 pemerintah menetapkan 3 kriteria DAK yaitu kriteria umum, kriteria khusus, dan kriteria teknis. Kriteria umum ditetapkan melalui pertimbanggan kemampuan keuangan daerah dalam APBD. Kriteria khusus ini ditetapkan melalui pertimbanggan peraturan Perundang-undangan dan karakteristik daerah, sedangkan kriteria teknis ini ditetapkan melalui kementrian negara atau departemen teknis.

\section{Belanja Modal}

Belanja Modal sesuai dalam pasal 50 huruf c Permendagri No. 59 Tahun 2007 mengenai perubahan Permendagri No 13 Tahun 2006 mengenai pengelolaan Keuangan Daerah untuk pengeluaran yang dilakukan dalam rangka pengadaan aset tetap berwujud yang memiliki nilai manfaat lebih dari 12 bulan yang digunakan untuk kegiatan pemerintahan. Pada pasal 53 aya 2 Permendagri No 59 Tahun 2007 dijelaskan bahwa nilai asset tetap berwujud yang di anggarkan dalam Belanja Modal sebesar harga beli dan bangun aset ditambah seluruh belanja terkait dengan pengadaan/pembangunan aset sampai tersebut siap digunakan.

\section{Indeks Pembangunan Manusia}

Menurut BPS (2009), IPM adalah ukuran pencapaian pembangunan didasarkan sejumlah komponen dasar dari kualitas hidup. IPM dihitung dengan data yang dapat menggambarkan empat komponen, yaitu keaksaraan dan rata-rata lama keberhasilan sekolah dalam pendidikan, harapan hidup yang mengukur keberhasilan dalam kesehatan dan kemampuan daya beli masyarakat untuk melihat kebutuhan dasar dilihat dari perpendekatan pengeluaran pendapatan perkapita yang mengukur keberhasilan di bidang pembangunan untuk kehidupan yang layak.

Menurut Human Development Report (1990), perkembangan manusia merupakan proses memperbesar pilihan orang ("suatu proses memperbesar orang"). Dari definisi itu ditarik kesimpulan bahwa fokus pembangunan suatu negara adalah penduduk, dikarena penduduk merupakan kekayaan riil suatu negara. Konsep atau definisi pembangunan manusia pada dasarnya mencakup dimensi pembangunan yang luas. Dalam konsep pembangunan manusia, pengembangan harus dianalisis dan dipahami dari sudut pandang manusia, tidak hanya dari pertumbuhan ekonominya. Definisi ini lebih luas dari definisi pembangunan yang menekankan hanya pertumbuhan ekonomi.

\section{Pengembangan Hipotesis}

\section{Pendapatan Asli Daerah Terhadap Indeks Pembangunan Manusia}

PAD ini bersumber dari pajak dan retribusi daerah yang dibayarkan oleh masyarakan sesuai dengan undang-undang. Alokasi dari PAD digunakan untuk meningkatkan sarana dan prasarana dibidang pendidikan kesehatan dan ekonomi. Pajak dan retribusi yang telah dibayarkan masyarakat akan kembali dinikmati oleh masyarakat itu sendiri. Dengan demikian peningkatan kualitas pelayaan dibidang ekonomi, pendidikan dan kesehatan dapat meningkatkan kesejahteraan masyarkat. Kesejahteraan masyarakat tercermin dalam angka IPM. Sehingga dapat disimpulakan bahwa jika PAD suatu daerah meningkat maka akan berbanding lurus dengan peningkatan IPM daerah tersebut Berdasarkan uraian diatas, dapat dirumuskan hipotesis sebagai berikut: 
H1: Pendapatan Asli Daerah berpengaruh positif terhadap Indeks Pembangunan Manusia

\section{Dana Alokasi Umum Terhadap Indeks Pembangunan Manusia}

Dana Alokasi Umum bersumber dari APBN yang dialokasikan oleh pemerintah pusat kepada pemerintah daerah. DAU digunakan untuk menyamakan kemampuan keuangan daerah. Pemerintah daerah dapat menggunakan DAU sesuai dengan Peraturan Perundang-undangan yang diatur pemerintah pusat dengan tujuannya untuk meningkatkan pelayanan daerah kepada masyarakat. Sehingga dengan meningkatnya DAU tersebut bermuara juga pada peningkatan kesejahteraan masyarakat. Dimana ketika kesejahteaan masyarakat meningkat maka juga akan meningkatkan angka IPM pada daeah tersebut. Berdasarkan uraiaan diatas, dapat dirumuskan hipotesis sebagai berikut:

H2: Dana alokasi umum berpengaruh positif terhadap Indeks Pembangunan Manusia

\section{Dana Alokasi Khusus Terhadap Indeks Pembangunan Manusia}

Dana Alokasi Khusus tesebut merupakan dana yang dialokasikan oleh pemerintah pusat kepada daerah yang digunakan untuk kebutuan daerah pemerintah daerah dapat menggunakan DAK untuk mendanai kegiatan khusus pemerintah daerah yang menjadi prioritas bagi pemerintah pusat. Pemerintah daerah mengaloksikan ini melalui pembangunan infrastruktur yang dapat menunjang kegiatan masyarakat terkait ketiga faktor yang dapat mempengaruhi tingkat capaian IPM setiap tahunya. Berdasarkan uraian diatas, dapat dirumuskan hipotesis sebagai berikut:

H3: Dana Alokasi Khusus berpengaruh positif terhadap Indeks Pembangunan Manusia.

\section{Pengaruh Pendapatan Asli Daerah Terhadap Indeks Pembangunan Manusia melalui Belanja Modal}

Realisasi dari pengalokasian PAD ini disalurkan untuk pembangunan di daerah misalnya sarana dan prasarana transportasi, tempat ibadah dan pembangunan lainya yang dapat meningkatkan Indeks Pembangunan Manusia (IPM). Besar kecilnya dana PAD pada suatu daerah dapat mengurangi ketergantungan terhadap pemerintah pusat. PAD setidaknya dapat digunakan untuk pembangunan jalan raya yang sumber dari dananya dari pajak kendaraan bermotor dan pajak bahan bakar, selain itu pembangunan fasilitas kesehatan bersumber dari retribusu pelayaan kesehatan yang diberikan oleh pemerintah daerah kepada masyarakat. Sehingga dalam hal ini dimensi umur panjang dan sehat dalam IPM dapat tercapai dengan membangunan fasilitas kesehatan. PAD secara umum mempengaruhi belanja modal, walaupun dalam penelitian lain terdapat perbedaan hasil penelitian bahwa PAD tersebut berhubungan erat terhadap Belanja Modal. Berdasarkan dari uraian diatas dapat dirumuskan hipotesis

H4: Belanja modal memediasi pengaruh hubungan antara Pendapatan Asli Daerah dengan Indeks Pembangunan Manusia

\section{Pengaruh Dana Alokasi Umum terhadap Indeks Pembangunan Manusia melalui Belanja Modal}

Penggunaan dana ini diharapkan guna keperluan yang berorientasi pada kesejahteraan masyarakat yang merupakan tuntutan utama dari otonomi daerah. Saat kondisi masyarakat menjadi lebih baik maka pembangunan manusia akan juga meningkat. Ini ditunjang dengan penggunaan DAU yang sangat tepat pengalokasiaannya terhadap balanja modal pemerintah dengan membangun sarana dan prasarana yang gunakan oleh masyarakat. Jadi saat ini bukan sekedang 
alokasi DAU yang tinggi bagi kemajuan daerah yang dilihat dari kekayaan, melainkan apakah pengalokasian DAU yang lebih tinggi untuk belanja pemerintah gunan meningkatkan kesejahteraan masyarakat sehingga IPM daerah itu barada diatas angka rata-rata nasional. DAU dialokasikan salah satunya untuk membiayai Belanja Modal. Semakin besar kemampuan DAU dalam membiayai Belanja Modal, maka akan meningkatkan IPM. Sehingga dari penelitian terdahulu tersebut diharapkan bahwasanya variabel DAU berpengaaruh signifikan terhadap IPM melalui belanja modal. Berdasarkan uraian diatas dapat dirumuskan hipotesis:

H5: Belanja Modal Memediasi hubungan antara Dana Alokasi Umum dengan Indeks Pembangunan Manusia

\section{Pengaruh Dana Alokasi Khusus terhadap Indeks Pembangunan Manusia melalui Belanja Modal}

Dana Alokasi Khusus diharapkan mampu mendorong pemerintah daerah supaya bisa meningkatkan mutu Kualitas Pembangunan Manusia melalui Pengalokasian Anggaran Belanja Modal yang secara tidak langsung berpengaruh pada kesejahteraan masyarakat sendiri. Sebab DAK yang dikelola pemerintah daerah dengan baik dapat meningkatkan mutu pendidikan, meningkatkan pelayanan kesehatan dan paling tidak dapat mengurangi kerusakan infrastruktur pada daerah tersebut dengan demikian kesejahteraan masyarakat juga akan meningkat dan berdampak pada IPM yang bagus. Apabila DAK yang dialokasikan dari pemerintah pusat ke pemerinah daerah tinggi, maka Belanja Modal tinggi karena DAK digunakan untuk membayai Belanja Modal. Dengan belanja modal yang tinggi, diharapkan akan meningkatkan IPM didaerah tersebut. sehingga diharapkan bahwasanya variabel DAK dapat secara signifikan berpengaruh secara tidak langsung terhadap IPM melalui belanja modal. Berdasarkan uraian diatas dapat dirumuskan hipotesis:

H6: Belanja Modal Memediasi hubungan antara Dana Alokasi Umum dengan Indeks Pembangunan Manusia.

\section{METODE PENELITIAN}

Jenis Penelitian

Jenis penelitian ini adalah penelitian deskriptif kuantitatif yang bertujuan untuk menjelaskan fenomena empiris yang didukung pola hubungan antar variabel, karakteristik dan data statistik

\section{Populasi dan Metode Pengambilan Sampel}

Adapun populasi dalam penelitian ini adalah 19 kabupaten/kota se Provinsi Sumatera Barat tahun 2015-2017. Penentuan sampel pada penelitian ini menggunakan metode total sampling. Total sampling merupkan teknik penentuan sampel bila semua anggota populasi digunakan sebagai sample, hal ini sering dilakukan bila jumlah populasi relatif kecil, kurang dari 30 atau penelitian yang ingin membuat generalisasi dengan kesalahan yang sangat kecil. Total sampling juga sering diartikan sampel yang sudah maximum, ditambah berapapun tidak akan mengubah keterwakilan.

\section{Jenis dan Sumber Data}

Jenis data dalam penelitian adalah data sekunder, yang merupakan data yang dikumpulkan, diperoleh dan telah diolah terlebih dahulu oleh pihak lain. Sumber data pada penelitian ini diperoleh dari LRA yang dipublikasikan melalui website Direktorat jendral Perimbangan 
Keuangan Kementerian Keuangan Republik Indonesia dan untuk data Indeks Pembangunan Manusia berasal dari website Badan Pusat Statistik.

\section{Metode Pengumpulan Data}

Untuk mendapatkan data yang relevan sehingga dapat dianalisis, maka diperlukan pengumpulan data dengan metode dokumentasi dimana data yang digunakan dalam penelitian ini dikumpulkan dengan metode dokumentasi melalui mempelajari dokumen- dokumen dan data yang dibutuhkan, seterusnya penghitungan dan pencatatan dengan cara menghimpun informasi guna penyelesaian masalah berdasarkan data- data yang sangat relevan. Sumber dan penggunaan data statistik yang didapat dari data eksternal yaitu data yang diperoleh dari BPS (Badan Pusat Statistik) dan Dirjen Perimbangan Keuangan Pemerintah Daerah. Data ini bersifat kuantitatif yaitu data yang obyektif dan angka-angka.

\section{Metode Analisis}

Analisis yang digunakan pada data dalam penelitian ini menggunakan pendekatan Partial Least Square (PLS). Menurut Ghozali (2013), PLS adalah suatu pendekatan alternatif yang berubah dari pendekatan Structural Equation Modeling (SEM) berbasis kovarian menjadi berbasis varian. SEM (Software Amos \& Lisrel) biasanya menguji kausalitas/teori dengan 200-400 sampel sedangkan PLS lebih bersifat predictive model. PLS secara langsung dapat menganalisis variabel yang dibentuk dengan indikator refleksif dan formatif. Kelebihan dari PLS-SEM adalah dapat menyelesaikan berbagai model yang rumit serta kompleks dengan berbagai variabel eksogen dan variabel endogen dengan banyak indikator yang ada.

Model formal PLS menjelaskan variabel laten merupakan linear agregat dari indikatorindikatornya. Weight estimate untuk menghasilkan komponen skor variable laten yang berdasarkan bagaimana inner model (model struktural yang menghubungkan antar variabel laten) dan outer model (model pengukuran yaitu hubungan antara indikator dengan konstruknya) dispesifikasi untuk mengukur uji validitas dan reliabilitas model. Hasilnya adalah residual variance dari variabel dependen. Penelitian ini akan membahas 2 tahap analisa PLS, yaitu:

\section{Model Pengukuran (Outer Model)}

Analisa outer model mendifinisikan bagaimana setiap indikator berhubungan dengan variabel latennya. Menurut Abdillah et, al (2015) terdapat beberapa uji pada outer model, yaitu:

\section{a. Indikator Reliability \& Internal Consistency Reliability}

Evaluasi reliability ini digunakan untuk melihat apakah data yang digunakan dalam penelitian konsisten atau tidak. Menurut Abdillah et, al (2015) suatu indikator dikatakan baik jika indikator reliability nilai 0,40-0,60 dan dikatakan baik jika >0,70. Variabel laten dinyatakan reliabel apabila nilai composite reliability lebih besar dari 0,70 .

\section{b. Convergent Validitty \& Discriminant Validity}

Evaluasi validitas data dilakukan menggunakan discriminant validity dan converget validity, dimana evaluasi ini untuk melihat apakah variabel yang digunakan dalam penelitian akurat untuk pengolahan data. Rule of thumb dipakai untuk menilai validitas konvergen adalah nilai loading factor yang harus lebih tinggi dari 0,70 atau nilai AVE besar dari 0,5. Discriminant validity berhubungan dengan prinsip bahwa pengukur atau manifest variable konstruk yang 
berbeda seharusnya tidak berkorelasi tinggi. Cara mengujinya dengan melihat nilai pada cross loading untuk tiap variabel yang harus lebih besar dari 0,70 (Abdillah, et al:2015).

\section{Model Struktural (Inner Model)}

Analisa inner model dilakukan guna memastikan bahwa model struktural yang dibangun robust dan akurat. Inner model merupakan model struktural untuk memprediksi hubungankausalitas antar variabel laten. Menurut Abdillah, et al (2015) evaluasi inner model dapat dilihat melalui beberapa uji, yaitu:

\section{a. Koefisien Determinan $\left(\mathbf{R}^{2}\right)$}

Nilai koefisien determinasi digunakan untuk melihat kemampuan variabel eksogen menjelaskan variabel endogen. Semakin tinggi nilai koefisien determinasi maka semakin baik model. Pada model PLS melihat nilai $R$-Square dilihat dengan 3 kriteria, yaitu (1) apabila saat nilai $R$-Square berada di antara 0,25-0,50 maka dapat dinyatakan lemah, (2) apabila saat nilai $R$ Square berada di antara 0,51-0,75 maka dapat dinyatakan sedang, (3) apabila nilai $R$-Square berada $>0,75$ maka dinyatakan substansial.

\section{b. $\mathbf{F}^{2}$ untuk Effect Size}

Nilai $\mathrm{F}^{2}$ sebesar $0.02,0.15$, dan 0.35 dapat di interpretasikan apakah prediktor variabel laten mempuyai pengaruh lemah, medium, atau besar pada tingkat struktural.

\section{c. Path Coefficient (Uji Hipotesis)}

Pengujian hipotesis penelitian dalam PLS dilakukan dengan menggunakan simulasi sehingga dilakukan metode bootstrap sampel. Pengujian dengan bootstrapping juga untuk meminimalkan data ketidaknormalan data penelitian. Metode bootstrapping adalah suatu proses untuk menguji tingkat akurasi pada sampel. Metode bootstrapping dilakukan dengan melihat output path coefficient. Kriteria pengujian hipotesis melalui path coefficient dengan melihat output t-values. Menurut Abdillah, et al (2015) kriteria pengujian hipotesis, yaitu (1) jika T-values $\geq 1,96$ dengan alpha $5 \%$, maka hipotesis diterima serta pengaruh variabel dinyatakan signifikan, (2) jika T-values $\leq 1,96$ dengan alpha $5 \%$, maka hipotesis ditolak serta pengaruh variabel dinyatakan lemah.

\section{HASIL DAN PEMBAHASAN \\ Gambaran Umum Objek Penelitian}

Subjek dalam penelitian ini adalah kabupaten dan kota di Provinsi Sumatera Barat. Kabupaten dan kota yang ada di Provinsi Sumatera Barat berjumlah 12 Kabupaten dan 7 Kota. Penentuan sampel pada penelitian ini menggunakan metode Total Sampling. Metode Total Sampling ini digunakan karena sampel dalam penelitian ini relatif sedikit yaitu berjumlah 19 Kabupaten dan Kota di Provinsi Sumatera Barat. 
Tabel 4.1 Kabupaten dan Kota di Provinsi Sumatera Barat

\begin{tabular}{|l|l|}
\hline No & $\begin{array}{l}\text { Kabupaten dan Kota di } \\
\text { Provinsi Sumatera Barat }\end{array}$ \\
\hline 1 & Kabupaten Limapuluh Kota \\
\hline 2 & Kabupaten Agam \\
\hline 3 & Kabupaten Kepulauan Mentawai \\
\hline 4 & Kabupaten Padang Pariaman \\
\hline 5 & Kabupaten Pasaman \\
\hline 6 & Kabupaten Pesisir Selatan \\
\hline 7 & Kabupaten Sijunjung \\
\hline 8 & Kabupaten Solok \\
\hline 9 & Kabupaten Tanah Datar \\
\hline 10 & Kota Bukittingi \\
\hline 11 & Kota Padang Panjang \\
\hline 12 & Kota Padang \\
\hline 13 & Kota Payakumbuh \\
\hline 14 & Kota Sawahlunto \\
\hline 15 & Kota Solok \\
\hline 16 & Kota Pariaman \\
\hline 17 & Kabupaten Pasaman Barat \\
\hline 18 & Kabupaten Dhamasraya \\
\hline 19 & Kabupaten Solok Selatan \\
\hline
\end{tabular}

Sumber: BPS

\section{Hasil Penelitian}

\section{Evaluasi Model Pengukuran (Outer Model)}

Model pengukuran (outer model) digunakan untuk melihat hubungan antara indicator dengan variable latennya. Model pengukuran ini terdiri dari dua uji yaitu indicator reflektif dan indicator formatif. Uji indicator reflektif terdiri dari:

a. Uji indicator reliability dan \& internal consistency

Pengujian reliabilitas ini untuk melihat apakah data dalam penelitian konsisten atau tidak. Konstruk dalam penelitian dinyatakan reliable jika memiliki nilai composite reliability $>0,70$ dan cronbach alpha $>0,60$.

Tabel 4.2 Uji Indicator Reliability

\begin{tabular}{|l|l|l|}
\hline Konstruk & $\begin{array}{l}\text { Composite } \\
\text { reliability }\end{array}$ & $\begin{array}{c}\text { Cronbach } \\
\text { alpha }\end{array}$ \\
\hline $\mathrm{X} 1$ & 1.000 & 1.000 \\
\hline $\mathrm{X} 2$ & 1.000 & 1.000 \\
\hline $\mathrm{X} 3$ & 1.000 & 1.000 \\
\hline $\mathrm{Y} 1$ & 1.000 & 1.000 \\
\hline $\mathrm{Y} 2$ & 1.000 & 1.000 \\
\hline
\end{tabular}

Sumber: olahan penulis 2018 


\section{b. Uji Convergent Validity \& Discriminant Validity}

Validitas convergent dari mode pengukuran dengan menggunakan indicator reflektif dinilai berdasarkan nilai indikator-indikator yang mengukur konstruk tersebut. Uji konvergen dilakukan dengan melihat Pengujian discriminant validity dilakukan untuk membuktikan apakah indikator pada suatu konstruk akan mempunyai fornell larcker criterion terbesar pada konstruk yang dibentuknya dari pada fornell larcker criterion dengan konstruk yang lain. Berikut uji discriminant validity menggunakan software SmartPLS yaitu:

Tabel 4.3

\section{Uji Diskriminan Validitas}

\section{Discriminant Validity}

\begin{tabular}{|c|c|c|c|c|c|c|c|c|c|}
\hline \multirow[t]{2}{*}{ 且 } & \multirow[t]{2}{*}{ Fornell-Larcker... } & \multirow[t]{2}{*}{ 囯 } & Cross Loadings & ${ }_{2}$ & \multicolumn{2}{|c|}{ Copy to Clipboard: } & \multirow[t]{2}{*}{ Excel Format } & \multirow{2}{*}{\multicolumn{2}{|c|}{ R Format }} \\
\hline & & & $\mathrm{X} 1$ & $X 2$ & $X_{3}$ & Y1 & & & \\
\hline $\mathrm{X} 1$ & & & 1.000 & & & & & & \\
\hline $\mathrm{X} 2$ & & & -0.084 & 1.000 & & & & & \\
\hline$x_{3}$ & & & -0.171 & 0.922 & 0.946 & & & & \\
\hline $\mathrm{Y} 1$ & & & -0.068 & 0.290 & 0.357 & 1.000 & & & \\
\hline $\mathrm{Y} 2$ & & & -0.062 & 0.311 & 0.487 & 0.445 & & & \\
\hline
\end{tabular}

Sumber : olahan penulis 2018

Berdasarkan output di atas terlihat bahwa nilai selalu meningkat dari nilai semula.Selain uji indikator reflektif di atas terdapat juga uji indikator formatif. Uji ini digunakan untuk melihat hubungan kausalitas dari indikator ke variabel laten maupun antar indikator. Uji indikator formatif dilihat nilai multicollinearity pada output SmartPLS. Kriteria jika nilai VIF antara 5-10 maka indikator terjadi multikolinearitas. Berikut output multicollinearity dengan SmartPLS :

Tabel 4.4

Multicollinearity

\begin{tabular}{|c|c|}
\hline Proksi & VIF \\
\hline X1.1 & 1.004 \\
\hline X1.2 & 1.004 \\
\hline X2.1 & 1.019 \\
\hline X2.2 & 1.019 \\
\hline X3.1 & 2.777 \\
\hline X3.2 & 2.777 \\
\hline Y1.1 & 1.160 \\
\hline Y1.2 & 1.160 \\
\hline Y2 & 1.000 \\
\hline
\end{tabular}

Sumber: Olahan Penulis 2018 
Berdasarkan output di atas terlihat bahwa semua indikator yang digunakan memiliki angka VIF rentang 1.000-3.000 Hal ini bermakna indikator dalam penelitian terbebas dari masalah multikolinearitas.

\section{Pengujian Model Struktural (Inner Model)}

Pengujian inner model digunakan untuk melihat hubungan antar variabel laten. Inner model dilihat dari output $\mathrm{R}^{2}, \mathrm{~F}^{2}, \mathrm{Q}^{2}$ dan path coefficient..

\section{a. Koefisien determinasi $\left(\mathbf{R}^{2}\right)$}

Koefisien determinasi digunakan untuk melihat kemampuan variabel eksogen menjelaskan variabel endogen dalam penelitian. Pada penelitian ini saya menggunakan output dari $R$ Square dalam melakukan analisis data. Berikut hasil olahan data koefisien determinasi, yaitu :

Tabel 4.5

Uji Koefisien determinasi $\left(\mathbf{R}^{2}\right)$

\begin{tabular}{|c|c|c|}
\hline Variabel & R Square & $\begin{array}{c}\text { R square } \\
\text { Adjusted }\end{array}$ \\
\hline Belanja Modal & 0,257 & 0,206 \\
\hline IPM & 0,217 & 0,144 \\
\hline
\end{tabular}

Sumber : Olahan penulis 2018

b. Effect Size $\left(\mathbf{F}^{2}\right)$

Nilai Effect Size $\left(\mathrm{F}^{2}\right)$ digunakan untuk melihat kebaikan model penelitian. Berikut tabel hasil olahan peneliti untuk uji Effect size, yaitu:

Tabel 4.6

Effect Size

\begin{tabular}{|c|c|c|}
\hline & Y1 & Y2 \\
\hline $\mathrm{X} 1$ & 0,224 & 0,153 \\
\hline $\mathrm{X} 2$ & 2,289 & 0,021 \\
\hline $\mathrm{X} 3$ & 0,209 & 0,144 \\
\hline $\mathrm{Y} 1$ & & 0,012 \\
\hline $\mathrm{Y} 2$ & & \\
\hline
\end{tabular}

Sumber : Olahan penulis 2018

Berdasarkan tabel di atas menunjukan bahwa nilai effect size terendah sebesar 0,012 sedangkan nilai effect size paling tinggi sebesar 2,289.

\section{c. Prediction Relevance $\left(\mathbf{Q}^{2}\right)$}

Uji ini dilakukan untuk mengetahui kapabilitas prediksi variabel eksogen terhadap variabel endogen didalam penelitian menggunakan prosedur blindfolding. Berikut output uji prediction relevance, yaitu: 
Tabel 4.7

Blindfolding

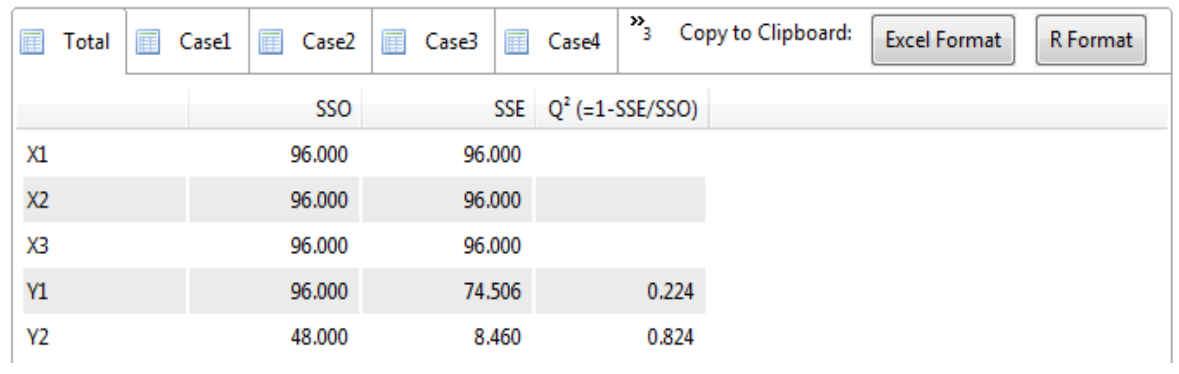

Berdasarkan tabel di atas terlihat kapabilitas prediksi Pendapatan Asli Daerah, Dana Alokasi Umum dan Dana Alokasi Khusus terhadap Belanja Modal sebesar 0,224. Sesuai kriteria yang ditetapkan kapabilitas prediksi Pendapatan Asli Daerah, Dana Alokasi Umum, dan Dana Alokasi Khusus terhadap Belanja Modal masuk kategori kapasitas prediksi sedang. Sedangkan kapabilitas prediksi Pendapatan Asli Daerah, Dana Alokasi Umum, dan Dana Alokasi Khusus terhadap Indeks Pembangunan Manusia melalui Belanja Modal masuk kategori kapasitas prediksi besar.

\section{d. Path Coefficient (UJi Hipotesis)}

Pengujian hipotesis pada SmartPLS versi 3.2.7 dilakukan dengan prosedur bootstrapping sample. Kriteria pengujian hipotesis melalui path coefficient dengan melihat output t-statistic dan original sample. Kriteria pengaruh hubungan variabel dinyatakan signifikan jika nilai $t$-statistic > 1,96 dan arah hubungan dilihat nilai original sample. Berikut ringkasan nilai $t$-statistic dan original sample untuk pengaruh langsung (direct effect) dan pengaruh tidak langsung (indirect effect) sebagai berikut:

Tabel 4.8

Uji Hipotesis

\begin{tabular}{|c|c|c|c|c|}
\hline Hubungan Variabel & t-statistic & Original sample & Arah hubungan & Keputusan \\
\hline $\mathrm{X}_{1}-\mathrm{Y}_{2}$ & 0,904 & $-0,048$ & negatif & ditolak \\
\hline $\mathrm{X}_{2}-\mathrm{Y}_{2}$ & 7,553 & 0,567 & positif & diterima \\
\hline $\mathrm{X}_{3}-\mathrm{Y}_{2}$ & 3,434 & 0,360 & positif & diterima \\
\hline $\mathrm{X}_{1}-\mathrm{Y}_{1}-\mathrm{Y}_{2}$ & 0,469 & 0,040 & positif & ditolak \\
\hline $\mathrm{X}_{2}-\mathrm{Y}_{1}-\mathrm{Y}_{2}$ & 1,708 & 0,215 & positif & ditolak \\
\hline $\mathrm{X}_{3}-\mathrm{Y}_{1}-\mathrm{Y}_{2}$ & 2,018 & 0,185 & positif & diterima \\
\hline
\end{tabular}

\section{Pembahasan}

\section{Hubungan Pendapatan Asli Daerah Dengan Indeks Pembangunan Manusia}

Penelitian ini menunjukan bahwa variabel Pendapatan Asli Daerah tidak terbukti berpengaruh terhadap Indeks Pembangunan Manusia. Maknanya, peningkatan pendapatan asli daerah yang terjadi tidak berperan terhadap peningkatan kualitas pembangunan manusia daerah tersebut.

Pendapatan Asli Daerah kabupaten/kota di Sumatera Barat tidak sama nilai nominalnya antar kabupaten/kota. PAD yang dipungut oleh pemerintah daerah melalui Pajak Daerah, Retribusi Daerah, Lain-lain pendapatan sah daerah belum berperan terhadap angka indeks pembangunan manusia Sumatera Barat. Sidik (2012) menegaskan bahwa keberhasilan peningkatan PAD 
hendaknya tidak hanya diukur dari jumlah yang diterima, tetapi juga diukur dengan perannya untuk meningkatkan indeks pembangunan manusia daerah agar dapat lebih berkembang, yang pada gilirannya dapat meningkatkan kesejahteraan masyarakat di daerah sehinga akan mencerminkan perkembangan perekonomian daerah. Hasil penelitian menunjukan pendapatan asli suatu daerah tidak berpengaruh terhadap peningkatan indeks pembangunan manusia yang mengindikasikan bahwa belum optimalnya pengelolaan pendapatan asli daerah oleh pemerintah dalam membangun masyarakat daerah itu.

\section{Hubungan Dana Alokasi Umum Dengan Indeks Pembangunan Manusia}

Penelitian ini menunjukan bahwa variabel dana alokasi umum terbukti berpengaruh signifikan positif terhadap Indeks Pembangunan Manusia. Maknanya, peningkatan dana alokasi umum yang terjadi berperan terhadap peningkatan kualitas pembangunan manusia daerah tersebut Adanya pengaruh DAU terhadap indeks pembangunan manusia disebabkan pengalokasian difokuskan oleh pemerintah daerah demi pembangunan manusia. Hal ini sesuai dengan fakta bahwa berdasarkan hasil pengukuran IPM di Sumbar, angka harapan hidup tahun 2017 di Sumbar yakni 68,78 tahun, harapan lama sekolah 13,94 tahun, dan rata-rata lama sekolah 8,72 tahun. Sedangkan pengeluaran perkapita pertahun oleh penduduk Sumbar sebesar Rp 10,036 juta. "Tren IPM di Sumbar terus naik. Sejak 2010-2017, IPM rata-rata tumbuh 0,85 persen per tahun," (Sumber: Republika.co.id) Data di atas menunjukan adanya peranan DAU terhadap indeks pembangunan manusia di wilayah Sumatera Barat. Hal ini sesuai dengan hasil penelitian bahwa DAU berpengaruh signifikan positif terhadap Indeks Pembangunan Manusia Sumatera Barat.

\section{Hubungan Dana Alokasi Khusus Dengan Indeks Pembangunan Manusia}

Penelitian ini menunjukan bahwa variabel dana alokasi khusus terbukti berpengaruh signifikan positif terhadap Indeks Pembangunan Manusia. Maknanya, peningkatan dana alokasi khusus (DAK) yang terjadi berperan terhadap peningkatan kualitas pembangunan manusia daerah tersebut.

Alokasi DAK Fisik di Provinsi Sumatera Barat secara total mengalami penurunan dari tahun 2016 sebesar 2,4 Triliun menjadi 1,84 Triliun pada tahun 2017 dan 1,73 Triliun pada tahun 2018. Di satu sisi Pemerintah Pusat dalam RPJMN 2014-2019 secara khusus memprioritaskan pembangunan infrastruktur yang masif di seluruh Indonesia. Peluang ini tentu harus bisa dikapitalisasi oleh pemerintah daerah untuk menggaet sebanyak mungkin dana perimbangan khususnya untuk pembangunan fisik melalui DAK Fisik. Alokasi dana perimbangan atau Transfer Ke Daerah dan Dana Desa (TKDD) cenderung meningkat setiap tahunnya dengan rerata pertumbuhan $8,3 \%$ per tahun. Peluang DAK dimanfaatkan oleh pemerintah kabupaten/kota di Sumatera Barat untuk meningkatkan indeks pembangunan manusia.

\section{Hubungan Pendapatan Asli Daerah Dengan Indeks Pembangunan Manusia Melalui Belanja Modal}

Penelitian ini menunjukan bahwa variabel Pendapatan Asli Daerah tidak terbukti berpengaruh terhadap Indeks Pembangunan Manusia melalui belanja modal. Maknanya, peningkatan pendapatan asli daerah yang terjadi tidak berperan terhadap peningkatan kualitas pembangunan manusia daerah tersebut ketika ada faktor belanja modal yang menjadi mediasi hubungan keduanya. Adanya belanja modal menjadi mediasi hubungan Pendapatan asli daerah dengan indeks pembangunan manusia terbukti tidak mampu meningkatkan pengaruh dari PAD 
terhadap pembangunan suatu daerah. Belanja modal yang dialokasikan pemerintah daerah belum maksimal dalam meningkatkan pembangunan suatu wilayah.

Kebijakan desentralisasi ditujukan untuk mewujudkan kemadirian daerah, pemerintah daerah otonom mempunyai kewenangan untuk mengatur dan mengurus kepentingan masyarakat setempat menurut prakarsa sendiri berdasar aspirasi masyarakat (UU No. 34/2004).

\section{Hubungan Dana Alokasi Umum Dengan Indeks Pembangunan Manusia Melalui Belanja Modal}

Penelitian ini menunjukan bahwa variabel Dana Alokasi Umum tidak terbukti berpengaruh terhadap Indeks Pembangunan Manusia melalui belanja modal. Maknanya, peningkatan Dana Alokasi Umum yang terjadi tidak berperan terhadap peningkatan kualitas pembangunan manusia daerah tersebut ketika ada faktor belanja modal yang menjadi mediasi hubungan keduanya. Setiap daerah tentu memiliki anggaran belanja modal masing-masing daerah. Belanja modal di alokasikan oleh setiap pemerintah daerah untuk pembangunan manusia masyarakat daerah tersebut.

Penggunaan DAU diserahkan kepada daerah sesuai dengan prioritas dan kebutuhan daerah untuk peningkatan pelayanan kepada masyarakat dalam rangka pelaksanaan otonomi daerah (Kemendagri.co.id). DAU memberikan pendapatan dalam jumlah besar untuk sebagian besar pemerintah daerah. Jumlah aktual transfer DAU diatur sesuai dengan beberapa kriteria, termasuk jumlah penduduk, luas wilayah, angka indeks pembangunan SDM, kapasitas fiskal dan kebutuhan fiskal (dihitung terutama berdasarkan gaji pegawai negeri sipil). Adanya DAU diharapkan perbedaan kemampuan keuangan antar daerah yang maju dengan daerah yang belum berkembang dapat diperkecil (Kemendagri.co.id).

\section{Hubungan Dana Alokasi Khusus Dengan Indeks Pembangunan Manusia Melalui Belanja Modal}

Penelitian ini menunjukan bahwa variabel dana alokasi khusus terbukti berpengaruh signifikan positif terhadap Indeks Pembangunan Manusia melalui belanja modal. Maknanya, peningkatan dana alokasi khusus (DAK) yang terjadi berperan terhadap peningkatan kualitas pembangunan manusia daerah tersebut ketika ada faktor belanja modal yang menjadi mediasi hubungan keduanya.

Dana alokasi khusus yang di peroleh oleh pemerintah kabupaten/kota di Sumatera Barat ternyata mampu meningkatkan indeks pembangunan manusia di wilayah sumatera barat dengan pengalokasian belanja modal di Sumatera Barat. Ini menjadi indikasi bahwa pemerintah kabupaten kota di sumatera barat memanfaatkan DAK yang telah di alokasikan melalui belanja modal secara efektif. Contoh saja DAK yang di alokasikan untuk belanja modal bidang infrastruktur irigasi yang diperoleh pemerintah kabupaten/kota se-Sumatera Barat pada tahun2017 (sumber: sda.pu.go.id). DAK ini secara tidak langsung mempermudah petani sumatera barat mengelola pertanian terutama sumber air bagi tanah pertanian. Ketika sumber air mudah diperoleh maka hasil pertanian akan meningkat. Jika hasil pertanian meningkat maka pendapatan petani meningkat serta berdampak pada peningkatan kesejahteraan petani. Tentu saja pada akhirnya indek pembangunan manusia di sumatera barat meningkat. Hal ini sesuai hasil penelitian bahwa DAK berpengaruh terhadap indeks pembangunan manusia melalui belanja modal. 


\section{KESIMPULAN, KETERBATASAN, dan SARAN}

Penelitian ini bertujuan untuk melihat pengaruh pendapatan asli daerah, dana alokasi umum dan dana alokasi khusus berpengaruh terhadap indeks pembangunan manusia melalui belanja modal. Berdasarkan hasil penelitian serta pengujian hipotesis baik hubungan langsung (direct effect) maupun hubungan tidak angsung (indirect effect) maka dapat di ambil kesimpulan sebagai berikut:

1. Pendapatan asli daerah berpengaruh signifikan terhadap indeks pembangunan manusia. Artinya semakin semakin tinggi pendapatan asli daerah maka indeks pembangunan manusia belum tentu mengalami kenaikan. Hipotesis pertama ditolak.

2. Dana alokasi umum berpengaruh signifikan posistif terhadap indeks pembangunan manusia. Artinya semakin tinggi dana alokasi umum maka semakin meningkat indeks pembangunan manusia.hipotesis kedua diterima.

3. Dana alokasi khusus berpengaruh signifikan positif terhadap indeks pembangunan manusia. Artinya semakin besar dana alokasi khusus maka semakin tinggi indeks pembangunan manusia. Hipotesis ketiga diterima.

4. Belanja modal tidak terbukti menjadi mediasi hubungan pendapatan asli daerah dengan indeks pembangunan manusia. Hipotesis keempat ditolak

5. Belanja modal tidak terbukti menjadi mediasi hubungan dana alokasi umum dengan indeks pembangunan manusia. Hipotesis kelima ditolak

6. Belanja modal tidak terbukti menjadi mediasi hubungan dana alokasi khusus dengan indeks pembangunan manusia. Hipotesis keenam diterima.

7. Hasil penelitian menunjukan kemampuan pendapatan asli daerah, dana alokasi umum dan dana alokasi khusus dalam menjelaskan indeks pembangunan manusia melalui belanja modal sebesar 14,4\% sedangkan sisanya 85,6\% dipengaruh oleh faktor lain di luar model penelitian ini.

Penelitian yang saya lakukan ini memiliki beberapa keterbatasan, yaitu:

1. Peneliti agak sulit mencari laporan keuangan pemerintah daerah di website pemerintah daerah masing-masing. Peneliti kadang harus mencari data laporan keuangan pemerintah daerah ke website kemendagri.

2. Peneliti hanya menggunakan sampel sebanyak 19 kabupaten kabupaten/kota se-Sumatera barat karena keterbatasan waktu yang peneliti miliki.

Berdasarkan kesimpulan di atas maka diberikan saran sebagai berikut:

1. Sebaiknya laporan keuangan pemerintah daerah tersedia di website semua pemerintah daerah agar penelitian mengenai pemerintah daerah efektif dan efisien.

2. Sebaiknya pemerintah daerah meningkatkan pengalokasian PAD untuk pembangunan kualitas masyarakat daerah tersebut.

3. Sebaiknya pemerintah daerah meningkatkan anggaran untuk pembangunan masyarakat daerah tersebut.

4. Bagi peneliti selanjutnya:

a. Sebaiknya peneliti selanjutnya menggunakan variabel lain di luar model penerlitian seperti variabel pertumbuhan ekonomi (Siswandi, 2015).

b. Sebaiknya peneliti selanjutnya menggunakan sampel seluruh kabupaten/kota se-pulau sumatera agar hasil penelitian lebih akurat. 


\section{DAFTAR PUSTAKA}

Abdillah, Willy dan Hartono, Jogiyanto. (2015). Partial Least Square (PLS) Alternatif Structural Equation Modeling (SEM) dalam Penenlitian Bisnis. Edisi.1. Yogyakarta: Penerbit ANDI.

Adiputera, I Made Pradana et al. 2014. Pengaruh PAD, Dana Perimbangan dan SiLPA terhadap Kualitas Pembangunan Manusia Dengan Belanja Modal Sebagai Variabel Intervening. Simposium Nasional Akuntansi XVII.

Ardiansyah dan Vitalis Ari Widiyaningsih.2014. Pengaruh Pendapatan Asli Daerah, Dana Alokasi Umum dan Dana Alokasi Khusus Terhadap Indeks Pembangunan Manusia Kabupaten/Kota Di Provinsi Jawa Tengah. Lombok: SNA 17 Mataram, Lombok.

Arikunto, S. (1998). Prosedur Penelitian Suatu Pendekatan Praktik. Jakarta: PT. Rineka Cipta.

Badan Pusat Statistik. 2014. Indeks Pembangunan Manusia dan Komponennya, 2015-2017. http://www.bps.go.id, diakses pada tanggal 20 Maret 2018.

Brassard, C. (2008). Decentralization, Democratization, and Development in Bhutan. Working Paper, February, Lee Kuan Yew School of Public Policy, National University of Singapore.

Brata, A.G. 2005. Investasi Sektor Publik Lokal, Pembangunan Manusia, dan Kemiskinan. Yogyakarta: Lembaga Penelitian-Universitas Atma Jaya.

Christy, Fhino Andrea dan Priyo Hari Adi. 2009. Hubungan Antara Dana Alokasi Umum, Belanja Modal dan Kualitas Pembangunan Manusia. The $3^{\text {rd }}$ National Conference UKWMS, Surabaya.

Darise, Nurlan, 2009 Pengelolaan Keuangan Pada Satuan Perangkat Kerja Daerah (SKPD) dan $B L U$, Indeks, Jakarta.

Darmayasa, 2014. Faktor Penentu Alokasi Belanja Modal dalam APBD. Simposium Nasional Akuntansi.

Darwanto dan Yulia Yustikasari. 2007. Pengaruh Pertumbuhan Ekonomi, Pendapatan Asli Daerah, dan Dana Alokasi Umum Terhadap Pengalokasian Anggaran Belanja Modal. Simposium Nasional Akuntansi X.

Ghozali, Imam. (2013). Aplikasi Analisis Multivariate dengan Progam IBM SPSS 21 Update PLS Regresi. Semarang: Badan Penerbit Universitas Diponegoro.

Harahap, Riva Ubar. 2011. Pengaruh Dana Alokasi Umum, Dana Alokasi Khusus, dan Dana Bgai Hasil Terhadap Indeks Pembangunan Manusia pada Kab/Kota Provinsi Sumatera Utara. Universitas Muhammadiyah Sumatera Utara. Vol 11 No. 1 Maret 2011.

Indriantoro dan Supomo. (1999). Metodologi Penelitian Bisnis untuk Akuntansi dan Manajemen. Edisi Pertama. BPFE Yogyakarta.

Jensen, M. dan Meckling, W. (1976). Theory of the Firm:Managerial Behavior, Agency Cost and Ownership Sturcture. Journal of Financial Economics (3), 305-360.

Jiwatami, Sandhyakalaning. 2013. Pengaruh Kemandirian Daerah, Dana Perimbangan, dan Belanja Pegawai Terhadap Belanja Modal Pemerintah Daerah (pada Kabupaten/Kota di Indonesia Periode 2008-2012). Simposium Nasional Akuntansi XVI, Manado, 25-28 September 2013.

Kusnandar \& Dodik Siswantoro. 2012. Pengaruh Dana Alokasi Umum, Pendapatan Asli Daerah, Sisa Lebih Pembiayaan Anggaran, dan Luas Wilayah terhadap Belanja Modal. Simposium Nasional Akuntansi XV. 
Lugastoro, Dectra Pitron. 2013. Analisis Pengaruh PAD dan Dana Perimbangan terhadap Indeks Pembangunan Manusia Kabupaten/Kota di Jawa Timur. (Tesis). Semarang: Universitas Diponegoro.

Maiharyati, Eva. 2010. "Pengaruh Pendapatan Daerah terhadap Indeks Pembangunan manusia dan Belanja Modal sebagai variabel Intervening pada Pemerintah Kabupaten/Kota di Nanggroe Aceh Darussalam”. Skripsi. Medan: Sekolah Pasca Sarjana, Universitas Sumater Utara.

Marhaeni, Harmawanti; Sri Yati dan Bambang Tribudhi M. 2008. Indeks Pembangunan Manusia Tahun 2006-2007. Jakarta: Badan Pusat Statistik.

Oktora, F. E. dan Wilson. 2013. Analisis Hubungan Pendapatan Asli Daerah, Dana Alokasi Umum, dan Dana Alokasi Khusus atas Belanja Modal Pada Pemerintah Daerah Tolitoli Sulawesi Tengah. Journal Accountability. 2(1)

Peraturan Pemerintah Nomor 71 tahun 2010 Tentang Standar Akuntansi Pemerintahan.

Peraturan Menteri Dalam Negeri No. 59 tahun 2007 tentang Pengelolaan Keuangan Daerah.

Raviyanti, Ayu Aldi et al.2017. Pengaruh PAD, DAU, DAK terhadap IPM dengan Belanja Modal sebagai Variabel Intervening. Jurnal Manajemen/Volume XXII, No. 02, 243-256.

Republik Indonesia. UU Nomor 23 Tahun 2014 tentang Pemerintahan Daerah Kementerian Dalam Negeri, Jakarta.

Scott, William R. (2011). Financial Accounting Theory, $6^{\text {th }}$ Edition, USA: Prentice Hall.

Setyowati, Lilis dan Yohana Kus Suparwati. 2012. Pengaruh Petumbuhan Ekonomi, DAU, DAK, PAD dengan Pengalokasian Anggaran Belanja Modal sebagai Variabel Intervening (Studi Empiris pada Pemerintah Kabupaten dan Kota se-Jawa Tengah). Jurnal Prestasi Vol. 9 No. 1.

Siswandi. (2015). Pengaruh Pertumbuhan Ekonomi, PAD dan Dana Perimbangan Terhadap Indeks Pembangunan Manusia Melalui Belanja Modal. Jurnal Assets. 5(2), 1-12.

Sugiyono. 2010. Metode Penelitian Bisnis. Bandung: Alfabeta.

Sularso, Sri. 2003. Buku Perlengkapan Metode Penelitian Akuntansi: Sebuah Perlengkapan Replikasi, BPFE-Yogyakarta.

Sumardjoko, Imam. 2013. Pengaruh Penerimaan Dana Otonomi Khusus Terhadap Indeks Pembangunan Manusia Papua dan Papua Barat Dengan Belanja Modal Sebagai Variabel Intervening. Simposium Nasional Akuntansi XIV, Lombok.

Syahril. 2012. Pengaruh Pendapatan Asli Daerah dan Belanja Modal Terhadap Indeks Pembangunan Manusiapada Kabupaten/Kota di Provinsi Sumatera Utara. Yogyakarta: Pusat Pengkajian Etika Politik dan Pemerintahan.

Todaro, Michael P. and Smith, Stephen C. 2011. Economic Development. Eleventh Edition. United States: Addison Wesley.

Undang-Undang Nomor 33 Tahun 2004 Tentang Perimbangan Keuangan Antara Pemerintah Pusat dan Pemerintah Daeran.

UNDP. 2004. Indonesia, Indeks Pembangunan Manusia. http://www.undp.or.id, diakses pada tanggal 20 Maret 2018.

Wandira Arbie Gugus. (2013). Pengaruh PAD, DAU, DAK dan DBH Terhadap Pengalokasian Belanja Modal. Accounting Analysis Journal. 1(3, 45-55. 